\title{
A sweltering afternoon Herberton, Far North Queensland
}

\section{Tass Holmes}

The University of Melbourne, Australia

\begin{abstract}
This short prose comprises childhood recollections interspersed with a brief contemporary travel 'memoir', juxtaposing past and present narratives in a limited gothic style. It conveys a sense of the sultry ambience of far north Queensland's tablelands region, inland from Cairns, with a particular focus on Herberton, a town in the 'dry tropics', with a mining history.
\end{abstract}

Keywords: tropical, Australia, memory, far north Queensland, gothic, remoteness 


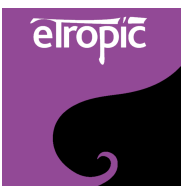

\[ \text { eTropic } 18.2(2019) \text { 'Tropical Gothic' } \]
he afternoon was hot.
There'd been an El Niño weather pattern, and infrequent rain.

$\mathrm{T}$ he afternoon was hot.

I'd just driven fleetingly to Herberton from the Kuranda marketplace, stopping to walk through the forest, to the rail line and the lookouts.

The heat and landscape evoked memories of childhood:

Summertime, the year I turned eleven...

Sunlight, slotted through top floor shutters, on the northwest side of a building.

Him seated there, his gnarled old hand uncurling, holding an amber stone.

The shade deep and dark on the eastern verandah.

The greyness of timbers, and things worn out by the sun.

Oppressive heat fading into late afternoon, as long shadows fell across a wide sloping street.

Who was he? I had to find out.

Earlier that afternoon, l'd been in the Kuranda rainforest, overlooking the lower reaches of the Barron River where it twists through the steep sides of the gorge, emptying onto a plain of sugar fields and mangrove-fringed tidal creeks. There I came across a goanna, creeping out from under a sprawling clump of yellow landscaping grass.

It had to be explained, this strange creature, to a young couple from France, who thought it was some kind of snake, and were afraid.

They began climbing up onto the visitor's seat at the lookout, to escape from the goanna, moving carefully, but as quickly as possible. They clutched a camera, and a small bag of possessions. The goanna approached them, as if not afraid of them at least, but soon lost interest. Instead it began stalking a dark northern bush turkey, despite the bird appearing too big for it to eat. 
I'd been dreaming childhood memories:

The concrete of the internal tool-shed floor was pockmarked with holes, used by generations of children on bright mornings, to crack macadamia nuts with a hammer or rock. Now the old woodwork tools lay on workbenches and shelves, coated with the dust of disuse. A yellowishgrey finely pulverised clay powder, that once was soil, filled the space beneath the tall, solid timber indoor staircase, where ant lion nests were visible.

A huge croc skull, cracked and bleached with age, graced the mossy porch beyond the living room, where people lounged in the afternoon with coffee or a beer, leaning against the shaded garden of bromeliads by the fence, or batting mozzies that emerged from the monstereosas on hot dark summer evenings. A tile-patterned brown croc skin, sporting a bullet hole inflicted by one of my bushman uncles, adorned the floor of polished cedar boards.

Some of those scrub turkeys, up there in the rainforest sections of bush that remain, besides scratching and pecking around in the abundant leaf litter of the long hot season, followed me around, or walked alongside me. It led me to think they were deliberate about this, familiar with people, no longer wild. But they also ran away timidly, rather than loitering, leaving a scattered impression that there were many of them - whereas, in these late days there were probably only a few left in that patch of forest.

The bush turkey, being stalked by the goanna, was acting brave. It avoided the big lizard only half-heartedly, even venturing towards it, feigning a strength it did not possess, warning the goanna off its scratching ground. Though it kept a sensible distance from those tough goanna jaws and the powerful, angular front legs with their curved claws, I had an ominous feeling the goanna would easily come out the victor in any real struggle.

The couple speaking French left, and I was momentarily alone.

The top of the stairs, the recess into the bunk room - a walk-through - was suffused with coolness during daylight, its poky verandah shaded and ornamented with flowering vines, overlooking the neighbour's bright lawn. But at night it loomed with long shadows that suggested 
intruders or frightening ghostly things. To go up there at bedtime, you were always some nervous kid, staying with too-old grandparents who couldn't help you, and you'd just finished watching a terrifying episode of Doctor Who on an old black and white TV screen. You'd been confronted, in your bulky aluminium space-suit, by a giant human-eating horror worm in the porous outer vestibule of a donut-shaped space-ship. You'd had to go out there, 'on deck', to check what was making that crunching noise.

Right there, in that vestibule, the vacuum of a spacey sky of the deepest black with no stars at all, could reach right in and get you. There was nothing that stood between you and sheer nothingness, nothing between you and death. Only the worm was lurking there in the metal scaffolding.

And then straight away it was bedtime, and you found yourself on those stairs, creeping up, listening to the trees scratching in a night wind just beyond the walls, alone.

The French couple was superseded by two blokes, one from middle Europe, perhaps Greece or Turkey, and the other an Asian man, possibly South Korean.

One of them commented to me about the strangeness of the sound of birds chirping, in an otherwise silent bush. His comment jogged me from my private musings.

Like me, the two men seemed interested in wildlife.

I thought they'd be frightened by the goanna, as the previous couple had been. Preemptively, to save them, I pointed out the goanna.

On being shown the big lizard, its rows of yellow spots incandescent in the lingering sunlight of the early dusk, the Mediterranean man, who - camera ready - was about to create landscape images of the river valley below us, quickly changed the direction in which he was pointing. He began, instead, to film the goanna, with its forked tongue flickering as it silently stalked the bush turkey. And then began to film me.

He was very excited, literally jumping and exclaiming wildly, while making his film.

I felt some strange aura invisibly present in the background, and, recalling the track I'd walked alone to get to the lookout, I thought it must be time to leave. With the man still uttering excited exclamations, and his friend chatting in broken English, I backed 
out cautiously, and walked quickly downhill on a dirt path in my broken thongs, towards where l'd parked the rental car.

I drove away hurriedly, coming down out of that jungle in the impending dusk, and not long afterwards, in the small car, I pressed on to Atherton.

At Halloran's Hill lookout, signs of the recent strong winds, rain and hailstorms that had struck the town were apparent. A light-blue timber post had blown over, rotten at the base. It lay at a skewed angle beside the road as I drove up, giving a curly impression - something from a Leunig watercolour, propped on a hedge of dark lillypillies where it had collapsed. Leaves and twigs from shrubs were strewn about the vacant building atop the hill, which had served as a museum or gallery-cafe.

Once you got to the top of the stairs it was okay. You could flick on the middle light, and huddle into the room, with its verandah doors shut tightly. But getting there at night was never an easy journey. The unpainted grey stairs creaked in specific places, and wore a light coating of dust. Spider webs drooped and hung in long sheets from struts of the high, bare clay-tiled roof.

A switch was set into textured concrete plaster at the bottom of the stairs, on a 'landing' above the wider living room. This turned on a yellowed incandescent light, that gleamed from the partial ceiling above the bottom landing.

At the top, another switch turned it off again, leaving the stairwell pitch black.

Occasionally the bulb was blown.

On Halloran's Hill, an older model four-wheel drive was parked, bonnet open, to cool its engine, after labouring up the range on this oppressive day. Two people waited, silhouettes on a hillside in the lucid evening after the rain squall. Light clouds, tinged a pale and dusky apricot, streaked across the tableland's sky.

They waited for engine cooling to set in. Viewed from my uphill position, the woman looked young and sporty. Her ponytail was blonde. She wore a peaked cap, shorts, and blush-coloured tee-shirt, in keeping with the mild sunset. She was seated on a yoga mat, and had assumed a half-lotus. Her ankles were crossed, back erect, as she stilled there, motionless and dedicated. Her thumbs and forefingers were joined. The backs of her hands rested on her knees. 
She emanated an encapsulated feeling, as if completely practiced in the task at hand, cultivating the studied obliviousness of 'higher awareness'. Her conscious intent was directed away from the car park. She faced the open plain to the south, where the expansiveness of undulant tableland country and low hills were verdant in the persistent heat, as grey clouds now streaked through an unearthly orange sky.

The man, in a blue-grey shirt, was seated at a picnic table, scant metres beyond a large clump of native grass. His greying head hung limply downwards, perhaps studying the weatherworn table surface.

I felt their palpable intent, to infuse their waiting with a determined sense of spirituality, unusual in such a setting: to not only wait, but to want to be inconspicuous doing so, thus seemingly purposeful, to have karmically chosen just the right time and location to be gifted an opportunity for silent reflection. They were allowing the cooling of the truck to take its own good time, so as to not rupture the peace of their waiting as the darkness began to creep in. In the falling dusk, I shivered uncontrollably. I couldn't help thinking they must be stuck without a mobile phone, or in a no-reception zone.

More memories came creeping back:

Tropical 'winter', in the work truck, age nineteen...

We were on a rough, muddy dirt road in the jungle, returning to our accommodation from a day job, some excursion to the middle of nowhere.

A dead python hung looped from a branch, directly at the low point where the truck was forced to stop, negotiating a damp ditch. Right at my window it appeared, unexpected. l'd looked up in sudden fright, seeing that thick whitishgreen limp shock of a thing. But it was only that. Just a fright, no real danger. It was dead as a doornail.

Not thinking of my own safety, I jumped into rescue mode, as if my intentionally 'good' act equated to helping an old woman cross a flooding river in a heavy downpour, rather than interrupting someone's meditation practice on a warm evening. I strode boldly down the hill, to gain the woman's attention. I needed to reassure myself these two stranded folk did not need assistance, because the sun was low. Light was fading from the sky, and a dark night was about to settle in. 
The woman, older than she appeared from a distance, opened her eyes and looked directly at me. She was not pleased to be interrupted, but gave a considered reply, in an Irish accent. Words to the effect that they were okay, thanks. Dismissive words. Strangers weren't required. Overheating was a familiar problem. She glanced uphill, barely, transiently, toward the truck. He'd turned his head and was staring up at us.

I decided these two were blanketed by a thick, insular feeling, a kind of isolation. I couldn't help them. They wanted to wait here. I abandoned them to their destiny, whatever it might be, and drove on, heading inland, up a much drier range.

Further up that second range was Herberton - 18 kilometres beyond the limit of the map that demarcates how far you're allowed to drive in a rented vehicle. I did not report this to the rental man the following day when I returned the vehicle, but I did sense he suspected l'd been up to something. He checked carefully and thoroughly in the boot of the car, standing there for several prolonged minutes, pondering, apparently searching, for any strange thing, or anybody, concealed in there, while I stewed in a plastic chair in the tropic afternoon, disguising my thoughts in the folds of a glossy brochure. I fooled myself it was a cache of tropical marijuana he'd been scouting for, something druggy, destined for the streets of southern cities, or smuggled pythons folded in small boxes, or cured cane toad skins. Something l'd forgotten in my carry bag.

He had such a serious look, hesitating to nod or grin, taking so long to check. I began to succumb to paranoia, for one fleeting moment.... What if there was something there...? But then he simply walked back into the office. All smiles. Nothing wrong.

In a sun-cooked springtime, age ten...

The vehicle was an old jeep, without sides, and no roof. It was nailed, rusted and sticky-taped together.

It took huge dug-out tracks, steep banks, and rough bush in its stride, tipping at untenable angles. We rode on the wheel covers, the side rims, the seats, holding on anywhere, as if to a yacht on a high sea, as if the up-anddown rollicking would go on forever. It was strenuous. There were many ways to fall off, even at slow speed.

My uncle's laughter resounded with joy however, his beard a shield against the high-running future, against 
'progress', as bits of the new day turned beneath the wheels, and we escaped another ditch.

I was a bush kid then - transplanted from home, close to the bigger southern city - for these holidays. My nephew was a bush baby, back in camp, where we'd showed off, my brother and $I$, out front of the tent with a dark-skinned skink crawling on our t-shirts. My brother was my best friend then, always beside me.

We went everywhere together, 'big kids', exploring with my uncle, rock-hopping, climbing steep gullies in the jeep, swimming in a silvery sun-reflecting river, slick through remote bushland, sliding over boulders, baking dry on broad granite. The sun had a cumulative kindness on our roving skins, spraying freckles across the bridge of my nose and tipping a copper sheen through my hair.

When we flew south, returning to my grandparents' house weeks later - what seemed like forever later - the early southern summer felt like frost-bite in the clear afternoons. My arms sprang to myriad goose-bumps, as a breeze rippled off the wide brown sluggish river.

Abundant low-growing eucalypts in the dry sclerophyll surrounding Herberton were parched by the scorching summer heat. On the winding road upward, dark trunks of trees resembled a burial ground. It seemed to have been completely burnt out by fires the previous year, recovering slowly, on account of the regular intensity of heat. No animals or birds appeared along that tired stretch of road.

Descending a short hill into Herberton, I expected an old-looking town, a shamble of brown and greying buildings, with a sense of poverty and distance recalled from childhood visits to tin-fossicker relatives. However, in the late evening, the pastel colours of renovated houses loomed like candy spots in the dusk. A diminutive old settlement appeared to my left. This historic mining village, settled in the gully, captures the sense of a moment in time for tourists. It held no ghosts, I thought.

Near the top of a parched and rocky hill, at the tourist info centre, I parked and limped around on tender feet. My thongs were beyond wearing. I gathered maps and stories from the outside notice-boards in the dwindling light. I was late. The tourist office was closed, as was the historic village. 
l'd have to return some other day, in the future.

Herberton today seems nothing like the dead end l'd imagined as an estranged visitor. I sensed a magnetic pull to be here again, like a great gnawing, an energy of longing, drawing me in to a nostalgic soaking in the hot silent emptiness of the bush.

Views from the town are a stark backdrop for a historian's or a miner's eye. It's a small place, lacking city services, surrounded by the high walls of hills. Above the hills hang straggling misshapen eucalypts, baked and torched in recent fires.

The dry tropic heat verges on unbearable, powerfully desiccating and shrivelling every exposed skin surface for tender southerners like me.

On the way out of town, I navigated downhill, along the main street, eyes peeled for a building that signified that one among my childhood memories of North Queensland. Nothing was recognisable.

I backtracked again, retracing a route up the steep rise to begin over. Surely it was that two-storey 'Queenslander' pub, hunkered right on the footpath near the apex of the challenging slope. It was painted, fixed up, regular-shaped. It had been restored.

My memory furnished an image of the building from a much earlier time, over forty years ago.

Summertime, childhood...

The late afternoon was hot, dry and baking in the dusty heat of the Queensland summer. This was not a problem. Summer was always my favourite season.

A tall set of stairs loomed above, and up there we walked, led by him, the old man, into the second storey of the pub, which was largely given over to his residence.

A singular miner, of hardened fossicking inclination, he was used to his own company. His face was cleanshaven, skin wizened and brown from many years spent working outdoors in the northern sun. He lived alone, surrounded by a collection of semi-precious stones, that were kept in good order, each stored and categorised for sale to rock collectors. He could pick them out from the 
lots in glass-fronted cabinets and old shelves, and reveal their value, their quality, their magical powers.

The sun-bleached walls were brownish grey inside, and silvery out, all unpainted, the building with an aura of angularity, of tumble-down, as if it was ancient, having stood up to an onslaught of unrelenting sunlight through many hot summers only by virtue of not having been wet much by rain. There was no rain. It was obliteratingly sunny, weakeningly hot. Day after day the heat beat down unforgivingly from a whitened, light-washed sky. Few buildings were left standing in the town then. The old pub, its front verandah suspended on long stilts, cast cool shadows across the footpath of the main street.

In his elevated home in the back of the top storey, the old man sat on a flat couch-bed, grateful for visitors, who were scarce. He never spent much time in the company of local folks, who knew him well enough. He smiled at me, a quiet young girl, not long ago lost for hours in the dry bush near a minor upstream tributary of the local river, near a rock gully, near an open clearing, near a sense of north and south, and east and west, in a place where purposeful walking, calm and courage could find an out and a way back, somehow, to camp.

I was grateful to be there too, narrating details of my ordeal. A timid, cautious man, he paid me close attention, quietly overjoyed that l'd strolled, for some inexplicable reason, briefly into his life for an afternoon. Children and womanly things had walked out on him decades earlier.

He asked my age, then said, 'Just wait here. I've got something for you.'

He left the room briefly, and went to an old cabinet in the shady, dim side of his humble abode. He took out a small smooth-polished rock that gleamed in the darkened room, with its scuffed floor. Returning to his accustomed seat on the couch-bed, he pressed into my hand a semi-opaque garnet, triangular and brownish-yellow. 
Thin sun lines slanted through closed timber slats that covered the window, across the back of the room, lighting the rock in my palm. I held it to the light, as he instructed. 'What is it?' I asked.

'It's a garnet,' he replied, seriously. 'It has a special quality, to protect you. It's made from the ancient resin of trees, that have become rock hard, over thousands of years, like a petrified tree rock. You keep it. It's yours.'

He was nodding.

I remember him, gentle, and quietly-spoken, finding joy in company of a child, so that his unaccustomed face lit up.

We had to go then. Someone was waiting for us outside.

I was led, perhaps holding a hand, down a steep long staircase into the welcome shade that the building and its leggy verandah threw across the hot road.

As we drove away, I looked back along the wide main street. I was sorry to leave Herberton behind, to leave the ambience of hot bushland that crunches underfoot, that finds a way back for you when you are lost, that bathes you on its sunny rock shelves, warms you in the strength of its daylight, and broadens your imagination with the eccentric determination of hardened fossickers. To leave and return to a city, a school, and a different kind of life, too often lived indoors, far away in southern Queensland, to what seemed then to be the extreme south.

I'm wondering now where that garnet went. As a young girl I had no way to value it, or predict how the memory would stay with me, and follow me, for what was to become decades, into adulthood. Perhaps I simply left it somewhere, in the palm of someone else's hand. 


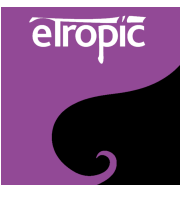

\section{Author's Note}

Herberton Royal Hotel ('HRH') was established 1880. The timber slats that shaded its upper floor verandah rooms in my memories are clearly visible in this image: https://www.gdaypubs.com.au/QLD/herberton/50727/royal-hotel.html retrieved March 2019. Views over the main street from the front verandah of the pub, on State Route 52 , built over the central road that used to be known as 'Broadway' - particularly looking to the south - remain almost exactly as I remembered from 1974. 